\title{
The Importance of ICTs for Students as a Competence for their Future Professional Performance: the Case of the Faculty of Business Studies and Tourism of the University of Huelva
}

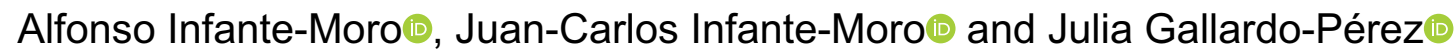 \\ Department of Financial Economics, Accounting and Operations Management, University of Huelva, Spain
}

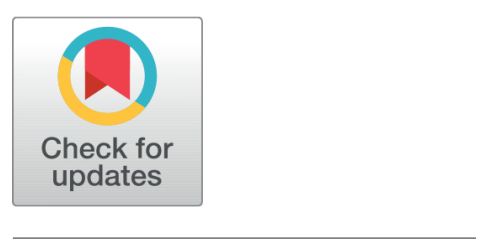

Received 25-04-2019

Revised 01-05-2019

Accepted 17-05-2019

Published 15-07-2019

Corresponding Author

Alfonso Infante-Moro,

alfonso.infante@uhu.es

Universidad de Huelva, Campus de "La Merced". Plaza de la Merced, 11, 21.071, Huelva, Spain

DOI https://doi.org/10.7821/

naer.2019.7.434

Pages: 201-213

Distributed under

Creative Commons CC BY 4.0

Copyright: (C) NAER Journal of New Approaches in Educational Research 2019

\section{OPEN ACCESS}

\section{ABSTRACT}

To date, the knowledge and use of ICT (Information and Communication Technologies) has become an almost essential requirement when someone wants to find employment in our society. For this reason, this study aims to analyze the importance that students of the Faculty of Business Studies and Tourism of the University of Huelva (Spain) give to the acquisition of ICT skills for their future professional performance and the domain they have over them (achieved throughout their years of learning). This research is developed through a questionnaire completed by 90 students of the Faculty and concludes that in general they give these ICT skills the importance that they deserve and that their domain goes in parallel (except for some skills that show formative need), even being able to observe that in the majority of cases the dominion of these skills is tied to the importance that they give them.

Keywords SKILL REQUIREMENTS, INFORMATION TECHNOLOGY, LEARNING, HIGHER EDUCATION

\section{INTRODUCTION}

Today the knowledge and use of ICT (Information and Communication Technologies) has become an almost essential requirement when it comes to finding employment in our society. This fact has caused future workers, schools and universities to begin to relativize their use to the point that future workers enroll in ICT courses to increase their employability and that schools and universities, in addition to giving specific training in ICT tools, require their use in most of the subjects of the programs they offer (tools that students must subsequently use in the labor market).

For this reason, in this whole process of digital literacy this study is focused a little more on universities and their programs for establishing standards of competence and technological skills in their students, and has as its main objective to analyze the importance that 
students give to the acquisition of ICT skills for their future professional performance and the domain they have over them (achieved throughout their years of learning). And for this specific case, we will analyze the example of the Faculty of Business Studies and Tourism of the University of Huelva (Spain), where the degrees of "Administration and Business Management", "Finance and Accounting" and "Tourism" are taught.

To do this, this research will start from a survey of 90 students of that faculty whose questionnaire (composed of 43 items) has been extracted from the article "Design and validation of an instrument for evaluating the digital competence of university students", prepared by Castillo, Almenara, and Vidal (2017), where the process of construction of this questionnaire is developed and analyzed, including its psychometric characteristics and its validity for the study of technological competences in the students. An extra column has been added to ask the student the importance he places on these competences in his future professional career.

In the next point, the importance of ICT and ICT skills will be contextualized, both in the labor market and in education. Continuing with the methodology used and the analysis of the results in two specific points: knowing the degree of domain of these ICT competences by the students of said Faculty and the importance they give to the acquisition of these competences for their future professional performance, and understanding if there is any link between this domain and the given to it. Concluding the study with the evaluation of the obtained level and giving some recommendations to promote the domain of said competences.

\section{STATE OF ART}

The volume of information that enters, leaves and is processed in companies has increased at a dizzying pace in recent years (Lam \& McKercher, 2013; Moro, López, Ordaz, \& Moro, 2014) and consequently automated information systems are needed for optimal functioning (Guevara, 2004).

This change has not affected one specific area of companies, but it has affected all their departments (Gray, 2017; Infante-Moro, Infante-Moro, Martínez-López, \& García-Ordaz, 2015). There are countless functions and tasks that are currently computerized in companies: billing, accounting, treasury management, stock management, cost accounting, human resources management, payroll, budget accounting, customer management,... And, at any one time, countless computer tools that workers of these companies should use, some more general: spreadsheets, word processing packages, databases,..., and others more specific to the area: invoices, computerized payroll and accounting, TPS, ERP,...

Consequently, it means that the number of computers and terminals that can be seen in a company has increased and that, therefore, one of the competencies demanded by companies when looking for workers is ICT skills (Falk \& Biagi, 2017; Infante-Moro, Infante-Moro, Martínez-López, \& García-Ordaz, 2016).

Thus, the training centers and universities have had to take note of this fact and act on it. Therefore, we should not only see this technology implanted in management process, 
because it also has to be included in teaching, both in tools used in the teaching process and in the inclusion of learning and use of ICT tools (which will later be used in the labor market) plus in their study programs (Dave, 2019; Gil-Flores, Rodríguez-Santero, \& TorresGordillo, 2017; Shukla \& Yadav, 2019).

Regarding the tools used in the teaching process, there are many ICT tools attached: tele-training platforms (Canals \& Minguell, 2018), MOOCs (Infante-Moro, Infante-Moro, Torres-Díaz, \& Martínez-López, 2017; López, Bernal, Leiva, \& Martín, 2018; Torres-Díaz, Moro, \& Díaz, 2014), intelligent tutorial systems (Pedroza, González, Guerrero, Collazos, \& Lecona, 2018), serious games (Callaghan, Savin-Baden, McShane, \& Eguiluz, 2017; Vera, Rodríguez, \& Moreno, 2018; Vlachopoulos \& Makri, 2017), social networks (Dumpit \& Fernandez, 2017; Pérez, 2018; Puertas-Hidalgo \& Carpio-Jiménez, 2017; Soler-Adillon, Pavlovic, \& Freixa, 2018), virtual simulators (Duque \& Pérez, 2018; Sánchez \& Aguirre, 2018), which provide skills when dealing with these technologies.

Furthermore regarding the inclusion of learning and the use of ICT tools in their study programs, authors such as Fernández, Leiva, and López (2017), Rodríguez and Gómez (2017), Martínez-Olvera and Esquivel-Gámez (2017), Ribeiro, Caldeiro-Pedreira, and Aguaded (2018), López-García and Martínez (2018), Creer (2018) and Serna-Tuya, González-Calleros, and Navarro (2018) demonstrate this in their studies, which provide a series of ICT competences (based on its learning and use) that will later be used in the labor market and will open the doors to applicants when acquiring a job.

In this way, this paper tries to analyze the mastery that students of the Faculty of Business Studies and Tourism of the University of Huelva (Spain) have on these ICT competences and the importance they give to the acquisition of these for their future professional performance, checking whether or not they are at the level required by the labor market or if corrective measures must be taken by the Faculty.

\section{METHODOLOGY}

As mentioned in the introduction, the method used to capture the data required in this research is the survey, whose questionnaire allows us to work with quantitative and empirical data, and allows us to achieve the proposed objectives.

A questionnaire with 43 items, formed by evaluative questions in base ten and without identification variables to avoid the absence of answers, and extracted from the article "Design and validation of an instrument for evaluating the digital competence of the university student" (Castillo et al., 2017), where the process of construction of this questionnaire is developed and analyzed, its psychometric characteristics and its validity for the study and evaluation of technological competences in students. To which an extra column is added to ask the student the importance that is given to those skills in their future professional career.

This instrument was built taking as reference the indicators proposed in the NETS ${ }^{\star} S$ Project (ISTE, 2007), developed by the International Society for Technology in Education (ISTE), and ratified by the expert judgment technique, delivered to 17 teachers from the 
Educational Technology area of different universities, both national and Latin American, who evaluated the questionnaire and verified that it fulfilled the psychometric characteristics of validity and reliability needed.

The 43 items that permit analysis:

- Technological literacy, observing if they understand and use information and communication technology systems (items 01,02 and 03), if they select and use applications effectively and productively (items $04,06,07,08,09,10$ ), if they investigate and solve problems in systems and applications (item 05), and if they transfer existing knowledge to ICT learning (items 11 and 12).

- The search and treatment of the information, observing if they plan strategies that guide the investigation (item 13), if they locate, organize, analyze, evaluate, synthesize and use information from a variety of sources and means (item 18), if they evaluate and select information sources and digital tools to perform specific tasks (items 14 and 15), and if they process data and communicate results (items 16 and 17).

- Critical thinking, problem solving and decision making, observing if they identify and define authentic problems and significant questions to investigate (item 19), if they plan and administer the necessary activities to develop a solution or complete a project (item 20), if they gather and analyze data to identify solutions and / or make informed decisions (item 21), and if they use multiple processes and different perspectives to explore alternative solutions (item 22).

- Communication and collaboration, observing if they interact, collaborate and publish with colleagues or other people, using a variety of environments and digital media (items 23, 26, 29, 30 and 31), if they effectively communicate information and ideas to multiple audiences, using a variety of media and formats (items 24 and 28), if they develop a cultural understanding and a global awareness through linking with students from other cultures (item 25), and if they participate in teams that develop projects to produce original works or solve problems (item 27).

- Digital citizenship, observing whether they promote and practice the safe, legal and responsible use of information and ICT (items 32, 33 and 34), if they exhibit a positive attitude towards the use of ICT to support collaboration, learning and productivity (item 37), and if they exercise leadership for digital citizenship (items 35 and 36).

- And creativity and innovation, observing if they apply existing knowledge to generate new ideas, products or processes (items $38,39,40$ ), if they create original works as means of personal or group expression (item 43), and if they identify trends and they foresee possibilities (items 41 and 42).

Thus, and returning to the study that is developed in this paper, this questionnaire is completed during the month of February 2018 by 90 students of the Faculty of Business and Tourism Sciences of the University of Huelva, where the degrees of "Administration and Business Management", "Finance and Accounting" and "Tourism" are taught, whose results allow us to analyze the importance that the students of this Faculty give to the acquisition 
of ICT skills for their future professional performance and the mastery they have over them (achieved throughout their years of learning).

The validation and verification that there is no confusion at the time of interpretation of the questions is developed previously with the realization of 5 "pilot surveys" to 5 students, after which no question had to undergo modifications.

And the size of the sample is determined by going to the formula of probability for defined populations, which ultimately gives us the number of answers necessary for the results to be significant at the academic level.

$$
n=\frac{Z^{2} x N \times p x q}{E^{2}(N-1)+Z^{2} x p x q}=90
$$

Where: $\mathrm{n}=$ Sample size; Confidence level $=95.5 \% ; \mathrm{Z}=2 ; \mathrm{N}=$ Frame size $=805$ students (total of students of the Faculty of Business Studies and Tourism of the University of Huelva); $\mathrm{E}=$ Error margin $=10 \%=0.1 ; \mathrm{p}$ and $\mathrm{q}=$ They are the variances of the population $=0.5$.

\section{RESULTS}

The results obtained are analyzed through descriptive statistics (means), which allows observation of if there are differences between the domain that the students of this Faculty have of the ICT competences and the importance that they give to the acquisition of these competences for their future professional performance, and through the Chi-square statistical model, which allows observation of if there are links or not between the mastery and the importance of ICT competences.

\subsection{Mastery and importance of ICT competences}

The means obtained in terms of the mastery and the importance that these students give to each of the items that form the questionnaire can be seen in the following table (Table 1):

Table 1 Average rating of students to the mastery andimportance of ICT competences. Source: Self made Items

Domain of Importance competence of competence

1. I am able to use different types of operating systems installed on a computer (Microsoft Windows, Linux, Mac,..) and mobile devices (iOS, Android, BlackBerry OS,...).

2. I am able to use different mobile devices (Smartphone, Tablet, PDAs,...).

3. I browse the Internet with different browsers (Internet Explorer, Mozilla Firefox, Safari, Opera,...).

4. I have mastered different office tools for the treatment of information, such as word processors, spreadsheets, databases,...

5. I research and solve problems in the systems and applications (configure email, configure antivirus, defragment the hard drive,...).

6. I am able to use different digital image, audio or video processing tools.

7. I can communicate with other people using synchronous communication tools via Web (chat, instant messaging services, Skype,...).
8,72

$8,94 \quad 8,92$

$6,96 \quad 8,84$

$6,26 \quad 8,31$

$6,47 \quad 7,29$

$8,49 \quad 8,57$
$7,62 \quad 8,17$ 
Table 1 continued

Items

8. I know how to design web pages using some computer program, including texts, images, audio, links,...

9. I know how to use collaborative work software using online Groupware tools (Google Apps, BSCW, OpenGroupWare,...).

10. I have mastered the Web 2.0 tools to share and publish resources online (Blog, Slideshare, Youtube, Podcast,...).

11. I use the virtual campus used in my University (Moodle. WebCt,...) as an effective support for face-to-face teaching.

12. I feel competent using virtual management (virtual secretary, Library services,...) of my University.

13. I am able to locate information through different sources and databases available on the Internet

14. I can identify the relevant information by evaluating different sources and its origin.

15. I am able to organize, analyze and ethically use information from a variety of sources and media.

16. I synthesize the information selected for the construction and assimilation of the new content, by means of tables, graphs or diagrams.

17. I use graphic organizers and software for the realization of conceptual and mental maps (CmapTool, Mindomo,...), diagrams or schemes, to present the relations between ideas and concepts.

18. I plan information searches to solve problems.

19. I am able to identify and define problems and / or research questions using ICT

20. I use the resources and digital tools for the exploration of current world issues and the solution of real problems, attending personal, social and professional needs.

21. I know how to analyze the capabilities and limitations of ICT resources.

22. I configure and solve problems that arise related to hardware, software and network systems to optimize their use for learning and productivity.

23. I share information of interest with my colleagues using a variety of environments and digital media.

24. I effectively communicate information and ideas to multiple audiences, using a variety of media and formats.

25. I am able to develop a cultural understanding and a global awareness through communication with other students and professionals from other cultures.

26. I know how to use computer programs (SlidShare, Google Docs,...) and technological tools to manage and communicate information with my colleagues and other users on the Internet.

27. I am able to coordinate group activities using the tools and means of the Internet.

28. I interact with other colleagues and users using social networks (Facebook, Ning, Twiter,...) and communication channels (Blog, canal Youtube,...) based on ICT.

29. I am able to work in professional networks (Linkedin,...).

30. I am able to design, create or modify a Wiki (Wikispaces, Nirewiki,...).

31. I know how to use social bookmarking to locate, store and tag Internet resources.

32. I assume an ethical commitment in the use of digital information and ICT, including respect for copyright, intellectual property and proper reference of sources.

33. I promote and practice the safe, legal and responsible use of information and ICT.

34. I show personal responsibility for lifelong learning using ICT.

35. I consider myself competent to make constructive criticisms, judging and making contributions to the ICT works developed by my colleagues.

36. I exercise leadership for digital citizenship within my group.

37. I exhibit a positive attitude towards the use of ICT to support collaboration, learning and productivity.

38. I have the ability to conceive original, novel and useful ideas using ICT.

39. I am able to create original works using traditional and emerging ICT resources.

40. I identify trends foreseeing the possibilities of using ICTs.

41. I use models and simulations to explore complex systems and topics using ICT.

42. I develop materials where I use ICT in a creative way, supporting the construction of my knowledge.

\begin{tabular}{|c|c|}
\hline $\begin{array}{l}\text { Domain of } \\
\text { competence }\end{array}$ & $\begin{array}{l}\text { Importance } \\
\text { of compe- } \\
\text { tence }\end{array}$ \\
\hline 5,32 & 7,77 \\
\hline 5,16 & 7,43 \\
\hline 7,07 & 7,83 \\
\hline 8,73 & 8,28 \\
\hline 7,62 & 7,61 \\
\hline 8,00 & 8,40 \\
\hline 7,82 & 8,04 \\
\hline 7,59 & 7,93 \\
\hline 7,24 & 7,78 \\
\hline 4,71 & 6,57 \\
\hline 6,10 & 7,02 \\
\hline 7,53 & 7,56 \\
\hline 7,20 & 7,81 \\
\hline 5,90 & 7,19 \\
\hline 5,43 & 8,18 \\
\hline 6,94 & 8,89 \\
\hline 6,38 & 7,48 \\
\hline 6,84 & 8,33 \\
\hline 7,02 & 7,79 \\
\hline 7,21 & 7,80 \\
\hline 8,53 & 8,16 \\
\hline 6,26 & 7,97 \\
\hline 4,82 & 6,33 \\
\hline 6,69 & 7,10 \\
\hline 6,72 & 8,14 \\
\hline 6,80 & 7,77 \\
\hline 6,47 & 7,66 \\
\hline 6,62 & 7,71 \\
\hline 5,38 & 7,11 \\
\hline 7,06 & 7,89 \\
\hline 6,72 & 8,21 \\
\hline 6,83 & 8,11 \\
\hline 5,93 & 7,59 \\
\hline 5,90 & 7,28 \\
\hline 6,13 & 7,61 \\
\hline
\end{tabular}

Continued on next page 
Items

43. I am able to adapt to new situations and technological environments.
Domain of Importance

competence of compe-

tence

9,36

Questionnaire for the study of ICT Competencies. Scale from 1 to 10 , where 1 refers to that you feel completely unable to do what is presented and 10 complete domination of what is presented.

In these averages calculated for each item, both for the mastery and for the importance, it can be seen that in general terms students value their own ICT skills and the importance of the acquisition of ICT skills for their future professional performance in a positive way.

Regarding the first variable analyzed, the mastery of ICT competences, the competency domains in which students are recognized with a lower level of training (average values lower than 5, on a scale of 1-10) and which could be considered as "weak points" are:

- Use of graphic organizers and software for the realization of conceptual and mental maps (CmapTool, Mindomo,...), diagrams or schemes, to present the relationships between ideas and concepts, belonging to item 17, with a value of 4.7 .

- And ability to design, create or modify a Wiki (Wikispaces, Nirewiki,...), corresponding to item 30 , with a value of 4.8 .

In contrast, competency mastery in which students are recognized with a higher level of training (average values higher than 8 , on a scale of 1-10) and which could be considered "strong points" are:

- Ability to use different mobile devices (Smartphone, Tablet, PDA,..), referring to item 02 , with a value of 8.9 , this one being the competence in which students have greater training.

- Ability to communicate with other people using synchronous communication tools via Web (chat, instant messaging services, Skype,...), corresponding to item 07, with a value of 8.49 .

- Effectively use the virtual campus employed in the University (Moodle. WebCt,...) as support for face-to-face teaching, belonging to item 11, with a value of 8.73.

- Interaction with other colleagues and users using social networks (Facebook, Ning, Twitter,...) and communication channels (Blog, YouTube channel,...) based on ICT, referring to item 28 , with an average of 8.5 .

- And ability to adapt to new situations and technological environments, belonging to item 43 , with a value of 8.3 .

The remaining competency domains have values between 5 and 8 , which can be considered satisfactory, when exceeding the average of the scale (5).

Regarding the other variable analyzed, the importance given by the students to the acquisition of the different competences presented for their future professional performance, the competences to which the students attach less importance are: 
- Use of graphic organizers and software for the realization of conceptual and mental maps (CmapTool, Mindomo,...), diagrams or schemes, to present the relationships between ideas and concepts, belonging to item 17, with a value of 6.6 .

- And ability to design, create or modify a Wiki (Wikispaces, Nirewiki,...), corresponding to item 30 , with a value of 6.3 .

As can be seen, both competences (17 and 30) coincide with the "weak points" defined in the previous variable referring to the level of training of the students.

On the contrary, the competences to which the students attach greater importance are:

- Ability to use different mobile devices (Smartphone, Tablet, PDA,...), referring to item 02 , with a value of 8.9 .

- Mastery of different office tools for the treatment of information, such as word processors, spreadsheets, databases, etc. corresponding to item 04 , with an average of 8.8 .

- Sharing information of interest with colleagues using a variety of environments and digital media, belonging to item 23 , with a value of 8.9.

- And ability to adapt to new situations and technological environments, belonging to item 43, with a value of 9.4 (this one being the most important competence for students).

In this case, it can be observed that two of the four most important competences considered coincide with the previous "strong points" (items 02 and 43).

In summary mode, the following figure shows the averages of the students' assessment of the domain and the importance of each one of the competences (Figure 1).

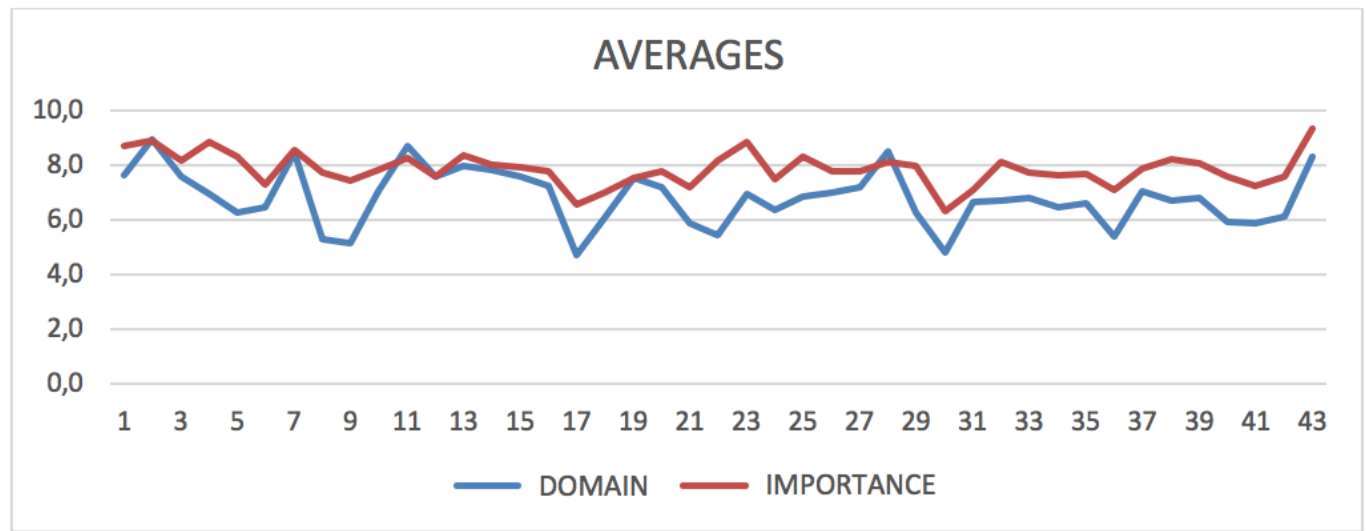

Figure 1 Graph of averages obtained in the assessment ofstudents to the domain and importance of ICT competences. Source: Self made. 


\subsection{Relationship between the domain and the importance of ICT competences}

This analysis of the averages reveals a possible link between the domain of ICT competences by students and the importance they give to the acquisition of these skills. In this way,Table 2 shows the results obtained in the Chi-square test, which allows us to see if there are links or not between the mastery and the importance of ICT skills.

Table 2 Chi-square test: existence ornot of link between domain and importance. Source: Self made.

\begin{tabular}{|c|c|c|c|c|c|c|}
\hline & Degree of Freedom & Level of Significance & $\begin{array}{l}\text { Critical } \\
\mathrm{X} 2\end{array}$ & Calculated X2 & Link & Probability of error \\
\hline Item 01 & 81 & $5 \%$ & 60,391 & 72,137 & SÍ & 0,000 \\
\hline Item 02 & 81 & $5 \%$ & 60,391 & 33,501 & NO & 0,030 \\
\hline Item 03 & 81 & $5 \%$ & 60,391 & 131,964 & SÍ & 0,000 \\
\hline Item 04 & 81 & $5 \%$ & 60,391 & 50,92 & NO & 0,116 \\
\hline Item 05 & 81 & $5 \%$ & 60,391 & 94,235 & SÍ & 0,007 \\
\hline Item 06 & 81 & $5 \%$ & 60,391 & 77,887 & SÍ & 0,297 \\
\hline Item 07 & 81 & $5 \%$ & 60,391 & 188,336 & SÍ & 0,000 \\
\hline Item 08 & 81 & $5 \%$ & 60,391 & 62,596 & SÎ & 0,198 \\
\hline Item 09 & 81 & $5 \%$ & 60,391 & 85,426 & SÍ & 0,032 \\
\hline Item 10 & 81 & $5 \%$ & 60,391 & 48,07 & NO & 0,470 \\
\hline Item 11 & 81 & $5 \%$ & 60,391 & 107,488 & SÍ & 0,000 \\
\hline Item 12 & 81 & $5 \%$ & 60,391 & 100,495 & SÎ & 0,000 \\
\hline Item 13 & 81 & $5 \%$ & 60,391 & 54,92 & NO & 0,004 \\
\hline Item 14 & 81 & $5 \%$ & 60,391 & 53,329 & NO & 0,031 \\
\hline Item 15 & 81 & $5 \%$ & 60,391 & 59,23 & NO & 0,009 \\
\hline Item 16 & 81 & $5 \%$ & 60,391 & 67,406 & SÍ & 0,141 \\
\hline Item 17 & 81 & $5 \%$ & 60,391 & 92,878 & SÍ & 0,049 \\
\hline Item 18 & 81 & $5 \%$ & 60,391 & 87,024 & SÎ & 0,024 \\
\hline Item 19 & 81 & $5 \%$ & 60,391 & 101,72 & SÍ & 0,051 \\
\hline Item 20 & 81 & $5 \%$ & 60,391 & 161,24 & SÍ & 0,000 \\
\hline Item 21 & 81 & $5 \%$ & 60,391 & 88,229 & SÎ & 0,094 \\
\hline Item 22 & 81 & $5 \%$ & 60,391 & 76,831 & SÍ & 0,611 \\
\hline Item 23 & 81 & $5 \%$ & 60,391 & 43,614 & $\mathrm{NO}$ & 0,653 \\
\hline Item 24 & 81 & $5 \%$ & 60,391 & 72,335 & SÍ & 0,197 \\
\hline Item 25 & 81 & $5 \%$ & 60,391 & 95,757 & SÍ & 0,006 \\
\hline Item 26 & 81 & $5 \%$ & 60,391 & 93,157 & Sí & 0,001 \\
\hline Item 27 & 81 & $5 \%$ & 60,391 & 53,797 & NO & 0,105 \\
\hline Item 28 & 81 & $5 \%$ & 60,391 & 74,191 & SÍ & 0,012 \\
\hline Item 29 & 81 & $5 \%$ & 60,391 & 69,496 & SÎ & 0,562 \\
\hline Item 30 & 81 & $5 \%$ & 60,391 & 66,017 & SÍ & 0,886 \\
\hline Item 31 & 81 & $5 \%$ & 60,391 & 108,507 & SÍ & 0,004 \\
\hline Item 32 & 81 & $5 \%$ & 60,391 & 68,985 & SÍ & 0,282 \\
\hline Item 33 & 81 & $5 \%$ & 60,391 & 63,037 & SÍ & 0,039 \\
\hline Item 34 & 81 & $5 \%$ & 60,391 & 105,261 & SÍ & 0,001 \\
\hline Item 35 & 81 & $5 \%$ & 60,391 & 56,157 & NO & 0,394 \\
\hline Item 36 & 81 & $5 \%$ & 60,391 & 73,217 & SÍ & 0,178 \\
\hline Item 37 & 81 & $5 \%$ & 60,391 & 91,963 & SÎ & 0,002 \\
\hline Item 38 & 81 & $5 \%$ & 60,391 & 87,706 & SÍ & 0,100 \\
\hline Item 39 & 81 & $5 \%$ & 60,391 & 54,825 & NO & 0,232 \\
\hline
\end{tabular}

Continued on next page 


\begin{tabular}{lllllll}
\hline & Degree of Freedom & $\begin{array}{c}\text { Table 2 continued } \\
\text { Level of Significance }\end{array}$ & $\begin{array}{l}\text { Critical } \\
\text { X2 }\end{array}$ & Calculated X2 & Link & Probability of error \\
\hline Item 40 & 81 & $5 \%$ & 60,391 & 112,227 & SÍ & 0,002 \\
Item 41 & 81 & $5 \%$ & 60,391 & 101,594 & SÍ & 0,012 \\
Item 42 & 81 & $5 \%$ & 60,391 & 118,35 & SÍ & 0,004 \\
Item 43 & 81 & $5 \%$ & 60,391 & 68,256 & SÍ & 0,000 \\
\hline
\end{tabular}

This test shows how the averages obtained confirm the existence in general, of a link between students' mastery of these competences and the importance they give to each one of them (Figure 2).

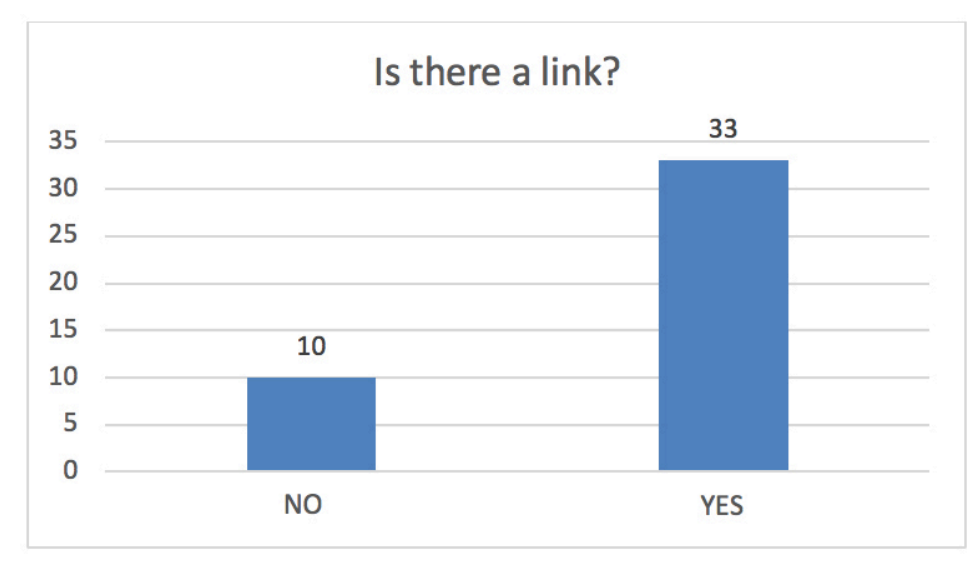

Figure 2 Graphof existence or not of link between domain and importance. Source:Self made.

This linkage exists in 33 of the 43 items analyzed, which means that in approximately $77 \%$ of the items, Pearson's $x^{2}$ is greater than the critical $x^{2}$, concluding that in 33 of the 43 items the students link the competence domain to the importance that they give to the acquisition of these for their future professional performance. Only in 10 items, this link does not exist between both valuations.

\section{DISCUSSION AND CONCLUSIONS}

ICT has a relevant role in today's society and in the labor market, which must be reflected in education and, therefore, in students (future workers of that society). Therefore, it is necessary to carry out an analysis to know the ICT skills training that students have and the importance they give to each one of these competences, in order to know the knowledge they possess and their training needs.

In this specific case, the analysis focuses on the students of the Faculty of Business Studies and Tourism of the University of Huelva (Spain), where the degrees of "Administration and Business Management", "Finance and Accounting" and "Tourism" are taught, and the results obtained regarding the importance that the students of this Faculty give to the acquisition of ICT skills for their future professional performance and the domain they have over them (achieved throughout their years of learning) are more than positive. 
These students have the necessary knowledge in ICT to face the next step they must take in their life, their introduction to the world of work. An elementary education is appreciated in these ICT competences, obtaining generally high average values for all the presented items, except for the competition regarding the use of graphic organizers and software for the realization of conceptual, mental maps, diagrams and schemes to present relations between ideas and concepts, and competence regarding the ability to design, create or modify a Wiki; for which students show training needs.

And with respect to the data obtained in relation to the importance they give to ICT competences, very positive results are also obtained, all the competences with values above the mean value are evaluated, which shows that students know the importance of the acquisition of those competences for the future work performance.

In general, these students give the importance that these ICT skills deserve and their mastery runs in parallel (except some competences that show formative need), even being able to observe that in the majority of the cases the mastery of these competences is linked to the importance they give to the acquisition of these for their future professional performance.

The analysis of the perceptions of the students of the Faculty of Business Studies and Tourism of the University of Huelva (Spain) on ICT competences gives a first view of the phenomenon, providing information on what the level of ICT competencies of current students in this Faculty is, but it would be necessary to delve deeper into other aspects such as the perspective of the teaching staff and the perspective of the companies, that is, the opinion of the professors and entrepreneurs on the level of mastery in these competences that the students and workers possess, and the importance that teachers and entrepreneurs give to possessing those skills to enter the labor market. This study should also be extended to other Faculties and other degrees.

Students, future workers, must be trained in the knowledge and use of new technologies, essential tools today in the world of work. These ones must develop creativity, communication, research, information management, problem solving, decision making and the concept and functioning of ICT, competences evaluated through the questionnaire; so the study programs should be able to foster an attitude of learning ICT skills that can be developed with years of study and professional practice. In addition to being able to relativize the acquisition of these ones, seeing the link between the importance given to the acquisition of those skills for future work performance and the mastery of them.

\section{REFERENCES}

Callaghan, M., Savin-Baden, M., McShane, N., \& Eguiluz, A. G. (2017). Mapping learning and game mechanics for serious games analysis in engineering education. IEEE Transactions on Emerging Topics in Computing, 5(1), 77-83. https://doi.org/10.1109/TETC.2015.2504241

Canals, P. C., \& Minguell, M. E. (2018). GaMoodlification: Moodle al servicio de la gamificación del aprendizaje. Campus Virtuales, 7(2), 9-25. https://doi.org/10.33115/udg_bib/cp.v7i14.22273

Castillo, J. J. G., Almenara, J. C., \& Vidal, L. I. E. (2017). Diseño y validación de un instrumento de evaluación de la competencia digital del estudiante universitario. Revista Espacios, 38(10). 
Creer, A. (2018). Introducing Everyday 'Digital Literacy Practices' into the Classroom: an Analysis of Multi-layered Media, Modes and their Affordances. Journal of New Approaches in Educational Research, 7(2), 131-139. https://doi.org/10.7821/naer.2018.7.265

Dave, D. (2019). An Analytical Study of the Role of ICT in Higher. Education. Journal of Global Economy, 15(1), 56-61.

Dumpit, D. Z., \& Fernandez, C. J. (2017). Analysis of the use of social media in Higher Education Institutions (HEIs) using the Technology Acceptance Model. International Journal of Educational Technology in Higher Education, 14(1), 5-. https://doi.org/10.1186/s41239-017-0045-2

Duque, A. G., \& Pérez, M. M. (2018). Percepción de los universitarios sobre la utilidad didáctica de los simuladores virtuales en su formación. Píxel-Bit. Revista de Medios y Educación, 53, 41-60. https://doi.org/10.12795/pixelbit.2018.i53.03

Falk, M., \& Biagi, F. (2017). Relative demand for highly skilled workers and use of different ICT technologies. Applied Economics, 49(9), 903-914. https://doi.org/10.1080/00036846.2016 .1208357

Fernández, E., Leiva, J. J., \& López, E. J. (2017). Formación en competencias digitales en la universidad. Percepciones del alumnado. Campus Virtuales, 6(2), 79-89.

Gil-Flores, J., Rodríguez-Santero, J., \& Torres-Gordillo, J. J. (2017). Factors that explain the use of ICT in secondary-education classrooms: The role of teacher characteristics and school infrastructure. Computers in Human Behavior, 68, 441-449. https://doi.org/10.1016/j.chb.2016.11 .057

Gray, C. (2017). Stage models of ICT adoption in small firms. In S. Zappala (Ed.), Impact of E-Commerce on Consumers and Small Firms (pp. 19-36). https://doi.org/10.4324/ 9781351156004-1

Guevara, A. (2004). Informática aplicada a la gestión de la empresa. Madrid: Pirámide.

Infante-Moro, A., Infante-Moro, J. C., Martínez-López, F. J., \& García-Ordaz, M. (2015). Currícula en SI/TI en las empresas españolas: Estudio longitudinal (2001-2011). Certiuni Journal, 1, $76-85$.

Infante-Moro, A., Infante-Moro, J. C., Martínez-López, F. J., \& García-Ordaz, M. (2016). Las competencias digitales en las grandes empresas del sector empresarial español. Tec Empresarial, 10(2), 41-49. https://doi.org/10.18845/te.v10i2.2654

Infante-Moro, A., Infante-Moro, J. C., Torres-Díaz, J. C., \& Martínez-López, F. J. (2017). Los MOOC como sistema de aprendizaje en la Universidad de Huelva (UHU). IJERI. International Journal of Educational Research and Innovation, 7, 13-24.

ISTE. (2007). NETS for students. Second edition (and others, Ed.). Retrieved from https://www.iste .org

Lam, C., \& McKercher, B. (2013). The tourism data gap: The utility of official tourism information for the hospitality and tourism industry. Tourism Management Perspectives, 6(0), 82-94. https:// doi.org/10.1016/j.tmp.2012.12.003

López, E. J., Bernal, C., Leiva, J. J., \& Martín, A. H. (2018). Validación del instrumento didáctico de valoración de observatorios digitales sobre MOOC: CUVOMOOC mediante el Método Delphi. Campus Virtuales, 7(1), 95-110.

López-García, A., \& Martínez, P. M. (2018). La realidad aumentada en la formación del profesorado. Una experiencia en las prácticas del Máster de Profesorado de Enseñanza Secundaria. Campus Virtuales, 7(2), 39-46.

Martínez-Olvera, W., \& Esquivel-Gámez, I. (2017). Estrategias de lectura comprensiva del inglés para bachilleres, apoyadas en materiales multimedia. Campus Virtuales, 6(1), 9-22.

Moro, A. I., López, F. J. M., Ordaz, M. G., \& Moro, J. C. I. (2014). Information exchange in big companies of the Spanish hotel sector: an inside and inter-organizational comparative analysis. 
University of the Algarve, School of Management, Hospitality and Tourism, 209-220.

Pedroza, B. E., González, J. M., Guerrero, J., Collazos, C. A., \& Lecona, A. A. (2018). Propuesta de un Tutor Cognitivo semi-automatizado con gamificación e interfaces tangibles para álgebra. Campus Virtuales, 7(1), 63-80.

Pérez, A. G. (2018). Social networks as tools to enrich learning environments in higher education. Bordón. Revista de pedagogía, 70(4), 55-71. https://doi.org/10.13042/Bordon.2018.60579

Puertas-Hidalgo, R., \& Carpio-Jiménez, L. (2017). Interacción generada en redes sociales por las universidades categoría A en Ecuador. International Journal of Information Systems and Software Engineering for Big Companies (IJISEBC), 4(1), 53-61.

Ribeiro, L. V. D. R., Caldeiro-Pedreira, M. C., \& Aguaded, J. I. (2018). Actividades de traducción con uso de tecnología para desarrollar la competencia comunicativa en las aulas de lenguas extranjeras. Campus Virtuales, 7(2), 27-38.

Rodríguez, R., \& Gómez, M. G. (2017). Competencias digitales en la enseñanza-aprendizaje del inglés en bachillerato. Campus Virtuales, 6(2), 51-59.

Sánchez, I. P., \& Aguirre, I. T. (2018). La importancia de los Centros de Simulación Empresarial en la formación universitaria. International Journal of Information Systems and Software Engineering for Big Companies (IJISEBC), 5(2), 115-122.

Serna-Tuya, A. S., González-Calleros, J. M., \& Navarro, Y. (2018). Las Tecnológicas de Información y Comunicación en el preescolar: Una revisión bibliográfica. Campus Virtuales, 7(1), 19-31.

Shukla, A., \& Yadav, B. K. (2019). A Study of Ict in Education: An Indian Prospective. International Journal of Research, 6(2), 33-45.

Soler-Adillon, J., Pavlovic, D., \& Freixa, P. (2018). Wikipedia in higher education: Changes in perceived value through content contribution. Comunicar, 54, 39-48. https://doi.org/10.3916/ C54-2018-04

Torres-Díaz, J. C., Moro, A. I., \& Díaz, P. V. (2014). Los MOOC y la masificación personalizada. Profesorado: Revista de curriculum y formación del profesorado, 18(1).

Vera, P. M., Rodríguez, R. A., \& Moreno, E. (2018). Gamificando la práctica de programación en el ámbito universitario. Campus Virtuales, 7(2), 55-68.

Vlachopoulos, D., \& Makri, A. (2017). The effect of games and simulations on higher education: a systematic literature review. International Journal of Educational Technology in Higher Education, 14(1), 22-. https://doi.org/10.1186/s41239-017-0062-1 